\title{
VALIDITAS DAN PRATIKALITAS MODUL STRATEGI PEMBELAJARAN KIMIA DENGAN PENDEKATAN DAUR BELAJAR ENAM FASE
}

\section{VALIDITY AND RELIABILITY OF CHEMISTRY LERNING STRATEGY MODUL BASE ON SIX PHASE-LEARNING CYCLE}

\author{
Fitriah Khoirunnisa* \& Ardi Widhia Sabekti \\ Jurusan Pendidikan Kimia, Universitas Maritim Raja Ali Haji \\ Jl. Politeknik Senggarang, Tanjungpinang, Kepulauan Riau 29115 \\ *Alamat Korespondensi: fitriahk@gmail.com
}

\begin{abstract}
Abstrak
Berdasarkan analisis kebutuhan yang telah dilakukan, maka perlu dikembangkan bahan ajar yang memfasilitasi siswa dalam mengkonstruk pengetahuannya tentang strategi pembelajaran pada bidang studi kimia. Penelitian ini bertujuan untuk mengembangkan modul perkuliahan Strategi Pembelajaran Kimia dengan pendekatan daur belajar enam fase. Pengembangan dilakukan dengan menggunakan model pengembangan 4D dengan mengambil tiga tahap awal (define, design, develop). Untuk mengukur kualitas modul dilakukan uji validitas dan uji praktikalitas. Dari ketiga validator, diperoleh nilai validitas 3,46 dengan kriteria valid. Dari uji coba terhadap mahasiswa, diperoleh nilai praktikalitas $81,74 \%$ dengan kriteria praktis.
\end{abstract}

Kata Kunci: modul, strategi pembelajaran, daur belajar

\begin{abstract}
Based on the needs analysis that had been done, it was necessary to develop teaching materials that facilitate students in constructing their knowledge of learning strategies in the field of chemistry studies. This research aim to develop the lecture module of Chemical Learning Strategy with six phase learning approach. This module developed using 4D by taking the first three stages (define, design, develop). The results shows that, the module are valid with a value of 3.46. The module are practical with a value of $81,74 \%$.
\end{abstract}

Keywords: module,learning strategy, learning cycle

\section{PENDAHULUAN}

Dalam kegiatan belajar mengajar, diperlukan keterlibatan pendidik, peserta didik, dan sumber belajar. Sumber belajar yang paling sering digunakan adalah bahan ajar. Menurut Daryanto dkk (2014) bahan ajar terdiri dari bahan ajar pandang (visual), bahan ajar dengan (audio), dan bahan ajar multimedia interaktif. Modul merupakan salah satu contoh bahan ajar pandang (visual).

Pemilihan bahan ajar berupa modul ajar dikarenakan modul telah menjadi kebutuhan yang sangat mendesak terutama di sekolah dan perguruan tinggi yang telah menggunakan kurikulum yang berorientasi pada keaktifan siswa
(Student Centered Learning). Modul dapat membantu pendidik dalam mewujudkan pembelajaran yang berkualitas. Penerapan modul dapat mengkondisikan kegiatan pembelajaran menjadi lebih terencana dengan baik, mandiri, dan dengan hasil (output) yang jelas. Beberapa modul telah dikembangkan untuk menunjang pembelajaran yang berkualitas, antara lain modul digital dengan pendekatan saintifik (Syahroni dkk, 2016), modul berbasis hasil penelitian pembelajaran (Parmin \& Peniati, 2012), modul berbasis indikator berfikir kritis (Khasanah dkk, 2017), modul berbasis kearifan lokal (Setiawan dkk, 2017), modul tematik dan inovatif berkarakter (Yunus \& Sanjaya, 2013), modul 
berbasis integrasi islam-sains (Yuliawati dkk, 2013), modul berbasis inkuiri (Hairida, 2016), dan modul berbasis perubahan konseptual radikal (Halim dkk, 2011),

Program studi pendidikan kimia di Fakultas Keguruan dan Ilmu Pendidikan, Universitas Maritim Raja Ali Haji, merupakan program studi baru di mana pada pelaksanaannya, mata kuliah Strategi Pembelajaran Kimia masih belum memiliki bahan ajar yang sesuai dengan kurikulum KKNI yang telah dirumuskan oleh program studi. Berdasarkan analisis kebutuhan yang telah diakukan oleh Khoirunnisa \& Sabekti (2017), maka perlu dikembangkan modul Strategi Pembelajaran Kimia dengan pendekatan Daur Belajar Enam Fase. Pemilihan pendekatan Daur Belajar Enam Fase didasarkan pada kebutuhan akan berlangsungnya proses pembelajaran yang berorientasi pada peserta didik (mahasiswa) sesuai dengan kurikulum KKNI yang lebih mengedepankan keaktifan mahasiswa dalam mengkonstruk pengetahuannya. Penelitan ini bertujuan untuk mengembangkan modul perkuliahan strategi pembelajaran kimia dengan pendekatan daur belajar enam fase yang valid dan praktis.

\section{METODE PENELITIAN}

Rancangan penelitian menggunakan model penelitian pengembangan 4D (define, design, develop, dan disseminate). Namun, penelitian kali ini hanya dibatasi sampai tahap develop karena keterbatasan waktu yang diberikan. Rancangan pengembangan modul dapat dijelaskan sebagai berikut:

\section{Tahap Pendefinisian (Define)}

Tahap ini bertujuan untuk menetapkan dan mendefinisikan syarat-syarat pembelajaran yang membutuhkan modul serta menganalisis materi yang dimasukkan ke dalam modul.

a. Analisis Kurikulum

Analisis kurikulum bertujuan menjadi dasar dalam merumuskan indikator dan capaian pembelajaran serta konsep-konsep yang dikembangkan pada modul.

b. Analisis Mahasiswa

Analisis mahasiswa merupakan telaah karakteristik mahasiswa yang merupakan pengguna modul, meliputi analisis usia, motivasi terhadap mata kuliah, kemampuan akademik, psikomotor dan keterampilan sosial.

c. Analisis Materi
Analisis materi bertujuan untuk menentukan isi dan materi perkuliahan sebagai konsepkonsep yang dikembangkan pada modul. Materi perkuliahan ditentukan berdasarkan learning outcomes yang telah dirumuskan pada kurikulum.

d. Perumusan Learning Outcomes

Perumusan learning outcomes berguna untuk merangkum hasil dari analisis konsep untuk menentukan perilaku objek penelitian. Kumpulan objek tersebut menjadi dasar untuk menyusun tes dan merancang perangkat pembelajaran yang kemudian di integrasikan ke dalam materi perangkat pembelajaran yang digunakan oleh peneliti.

Adapun pemaparan proses dan hasil tahap define telah dilaporkan oleh (Khoirunnisa \& Sabekti, 2017).

\section{Tahap Perancangan (Design)}

Tujuan tahap perancangan adalah untuk merancang modul sesuai dengan indikator dan learning outcomes yang telah ditentukan.

\section{Tahap Pengembangan (Develop)}

Tahap pengembangan bertujuan untuk menghasilkan modul yang valid dan praktis. Adapun langkah-langkahnya adalah sebagai berikut.

a. Uji Validitas Modul

Rancangan modul yang telah dibuat dikonsultasikan dengan validator mengenai validitasnya. Validasi dilakukan oleh validator yang terdiri dari tiga orang dosen. Validator ahli diminta untuk melihat kelayakan isi, penyajian, dan bahasa, serta memberikan kritik atau saran terhadap kekurangan yang ada pada modul. Revisi dilakukan berdasarkan saran-saran yang diberikan.

b. Uji Praktikalitas Modul

Setelah direvisi, modul diuji coba lapangan melalui uji coba terbatas kepada 38 mahasiswa semester lima tahun akademik 2017/2018 untuk mengetahui praktikalitas. Praktikalitas ditinjau dari aspek efektif, kreatif, efisien, interaktif, dan tampilan.

Penelitian dilakukan di Fakultas Keguruan dan Ilmu Pendidikan Universitas Maritim Raja Ali Haji (FKIP UMRAH) pada bulan Juli - Oktober 2017. Penelitian menggunakan teknik pengumpulan data berupa kuesioner dan wawancara. Data hasil validasi modul yang diperoleh, disajikan dengan menggunakan skala Likert, selanjutnya dicari rerata nilai dengan kriteria validitas menurut Sudjana (2006) berikut: 
1,00-1,99 : Tidak Valid

2,00-2,99: Kurang Valid

3,00-3,49: Valid

3,50-4,00 : Sangat Valid

Data tentang respon mahasiswa terhadap modul yang diperoleh dari angket, dianalisis nilai praktikalitas dengan menggunakan rumus persentase. Data tentang respon mahasiswa kemudian dianalisis menggunakan ketentuan yang dikonversikan ke dalam kategori praktikalitas menurut Sudjana (2006) berikut:

$$
\begin{array}{ll}
0-54 & : \text { Tidak Praktis } \\
55-64 & : \text { Kurang Praktis } \\
65-79 & : \text { Cukup Praktis } \\
80-89 & \text { : Praktis } \\
90-100 & \text { : Sangat Praktis }
\end{array}
$$

\section{HASIL DAN PEMBAHASAN Desain Modul}

Modul yang dikembangan terdiri atas tiga bab, yaitu Pendahuluan, Kegiatan Belajar, dan Evaluasi. Bab Pendahuluan berisi tentang kompetensi utama, kompetensi pendukung, deskripsi mata kuliah, prasyarat mata kuliah, petunjuk penggunaan modul, dan tujuan akhir. Bab Kegiatan Belajar terdiri atas tujuh kegiatan belajar, yaitu: (1) hakikat, ciri, dan komponen pembelajaran, (2) konsep dasar pembelajaran, (3) keterampilan dasar mengajar, (4) model pembelajaran, (5) strategi pembelajaran, (6) pendekatan pembelajaran, dan (7) metode, teknik, dan taktik pembelajaran. Kegiatan belajar disusun sesuai dengan tahap-tahap pada siklus belajar enam fase, yaitu identifikasi, invitasi, eksplorasi, eksplanasi, elaborasi, dan evaluasi.

Fase identifikasi membantu mahasiswa mengetahui tujuan dari kegiatan belajar. Fase invitasi membantu mahasiswa dalam menggali pemahaman yang dimilikinya serta memunculkan rasa ingin tahu mahasiswa. Fase eksplorasi membantu mahasiswa menggali informasi untuk mengkonfirmasi pengetahuan awalnya. Fase eksplanasi membantu mahasiswa dalam melengkapi, menyempurnakan, dan memperbaiki konsep awal yang telah dimilikinya. Fase elaborasi membantu siswa dalam menerapkn konsep yang teah dimilikinya pada situasi baru. Fase evaluasi membantu siswa dalam mengukur pencapaian belajarnya. Bab Kegiatan Belajar memuat studi kasus dan pertanyan-pertanyaan yang perlu dijawab mahasiswa untuk membantu konstruksi pengetahuannya.

\section{Validitas Modul}

Modul divalidasi oleh tiga orang dosen dengan menggunakan angket yang memiliki skala likert 1-4. Aspek yang divalidasi antara lain komponen kelayakan isi, penyajian, dan bahasa. Dalam mengembangkan modul, terdapat beberapa saran perbaikan yang diberikan oleh validator antara lain: (1) penyesuaian penamaan subbab, (2) penyesuaian kolom/ruang jawaban, (3) mengefektifkan kalimat, (4) penggunaan ejaan, dan (5) pemberian contoh-contoh yang relevan. Setelah perbaikan modul, diproleh nilai validitas modul 3,46 berkriteria valid dengan nilai kelayakan isi 3,55; kelayakan penyajian 3,4; dan kelayakan bahasa 3,33.

\section{Praktikalitas Modul}

Setelah divalidasi, modul diujicobakan terhadap 38 mahasiswa. Aspek praktikalitas yang diuji antara lain efektif, kreatif, efisien, interaktif, dan menarik. Hasil uji praktikalitas membrikan nilai $81,74 \%$ dengan kriteria valid, dengan nilai pada tiap aspeknya yaitu: (1) efektif memiliki nilai $81,98 \%$, (2) aspek kreatif memiliki nilai $80,06 \%$, (3) aspek efisien memiliki nilai 80,16 $\%$, (4) aspek interaktif memiliki nilai 80,26\%, dan (5) aspek menarik memiliki nilai 85,16\%.

Modul yang dikembangkan dengan pendekatan daur belajar dapat membantu mahasiswa dalam mengkonstruk pengetahuannya dengan baik, karena terdapat proses akomodasi dan asimilasi di dalamnya. Keefektifan Daur Belajar telah dibuktikan dalam beberapa penelitian, antara lain dalam meningkatkan kemampuan berfikir kritis (Cahyarini dkk, 2016), kreatifitas (Vincentrisia \& Suciati, 2015), dan mengatasi miskonsepsi (Taufiq, 2012).

\section{KESIMPULAN}

Berdasarkan hasil penelitian, disimpulkan bahwa modul Strategi Pembelajaran Kimia dengan pendekatan Daur Belajar Enam Fase yang dikembangkan adalah valid dengan nilai validitas 3,46 dan praktis dengan nilai praktikalitas $81,74 \%$.

\section{UCAPAN TERIMA KASIH}

Ucapan terima kasih disampaikan kepada Direktorat Riset dan Pengabdian kepada Masyarakat (DRPM) Dirjen Penguatan Riset dan Pengembangan Kemenristekdikti yang telah memberikan dukungan finansial terhadap penelitian ini. 


\section{DAFTAR RUJUKAN}

Cahyarini, A., Cahyarini, A., Rahayu, S., \& Yahmin, Y. (2016). The Effect of 5E Learning Cycle Instructional Model Using Socioscientific Issues (Ssi) Learning Context on Students' Critical Thinking. Jurnal Pendidikan IPA Indonesia, 5(2), 222-229. https://doi.org/10.15294/jpii.v5i2. 7683

Daryanto \& Dwicahyono, A. (2014). Pengembangan

Perangkat Pembelajaran (Silabus, RPP, PHB, Bahan Ajar). Yogyakarta: Gava Media

Hairida. (2016). The Effectiveness Using Inquiry Based Natural Science Module With Authentic Assessment To Improve the Critical Thinking and Inquiry Skills of Junior High. Jurnal Pendidikan IPA Indonesia, 5(2), 209-215. https://doi.org/10.15294/jpii.v5i2.7681

Halim, A., Meerah, S. T., \& Halim, L. (2011). Pengembangan Modul Pembelajaran Mandiri Berbasiskan Perubahan Konseptual Radikal. Jurnal Pendidikan Dan Pembelajaran, 18(2), 127-132.

Khasanah, A. N., Widoretno, S., \& Sajidan, S. (2017). Effectiveness of Critical Thinking Indicator-Based Module in Empowering Student's Learning Outcome in Respiratory System Study Material. Jurnal Pendidikan IPA Indonesia, 6(1), 187-195. https://doi.org/10.15294/jpii.v6i1.8490

Khoirunnisa, F., \& Sabekti, A. W. (2017). Analisis Kebutuhan Pengembangan Modul Ajar Strategi Pembelajaran Kimia Dengan Pendekatan Daur Belajar Enam Fase. Yogyakarta: Seminar Nasional Kimia Universitas NEGERI Yogyakarta.

Syahroni, N. R. Dewi, K. (2016). The Effect Of Using Digimon ( Science Digital Module ) With Scientific Approach At The Visualizationof Students '. Jurnal Pendidikan IPA Indonesia ,5(1), 116-122. https://doi.org/10.15294/jpii.v5i1.5800

Peniati, E. (2012). Pengembangan Modul Mata Kuliah Strategi Belajar Mengajar Ipa Berbasis Hasil Penelitian Pembelajaran. Jurnal Pendidikan IPA Indonesia, 1(1), 815. https://doi.org/10.15294/jpii.v4i2.4179

Setiawan, B., Innatesari, D. K., \& Sabtiawan, W. B. (2017). The Development of Local Wisdom-based Natural Science Module to Improve Science Literation of Students. Jurnal Pendidikan IPA Indonesia, 6(1), 4954. https://doi.org/10.15294/jpii.v6i1.9595
Sudjana, N. (2006). Penilaian Hasil Proses Belajar Mengajar. Bandung: Remaja Rosdakarya

Taufiq, M. (2012). Remediasi Miskonsepsi Mahasiswa Calon Guru Fisika Pada Konsep Daya Melalui Penerapan Model Siklus Belajar (Learning Cycle) 5E. Jurnal Pendidikan IPA Indonesia (Indonesian Journal of Science Education), 1(2), 198203. https://doi.org/10.15294/jpii.v1i2.2139

Vincentrisia, A., \& Suciati. (2015). Application Of Learning Cycle Model ( 5e ) Learning With Chart Variation Towardstudents , Creativity. Jurnal Pendidikan IPA Indonesia, $\quad 4(1), \quad 56-66$. https://doi.org/10.15294/jpii.v4i1.3502

Yuliawati, F., Rokhimawan, M. A., \& Suprihatiningrum, J. (2013). Pengembangan Modul Pembelajaran Sains Berbasis Integrasi Islam-Sains Untuk Peserta Didik Difabel Netra Mi/Sd Kelas 5 Semester 2 Materi Pokok Bumi Dan Alam Semesta. Jurnal Pendidikan IPA Indonesia. 2(2), 169-177. Retrieved from http://journal.unnes.ac.id/nju/index.php/jpii 